\title{
The Literature of the Copts and the Contributions of Monsignor Hyvernat to the Study of the Subject (Fourth Annual Henri Hyvernat Lecture)
}

\author{
Leo Depuydt \\ Department of Egyptology and Assyriology, Brown University, Providence, RI, USA \\ Email: leo depuydt@brown.edu
}

Received 13 July 2015; accepted 28 August 2015; published 1 September 2015

Copyright (C) 2015 by author and Scientific Research Publishing Inc.

This work is licensed under the Creative Commons Attribution International License (CC BY).

http://creativecommons.org/licenses/by/4.0/

c) (†) Open Access

\section{Abstract}

This paper is an extended version of the Fourth Annual Henri Hyvernat Lecture, read at 5:00 p.m. on March 26, 2015, in St. Thomas Aquinas Hall on the campus of the Catholic University of America in Washington DC. It was agreed to retain the text for the most part as a lecture, instead of turning it into an article, in order to retain the spirit of the event and honor the memory of the French-born Henri Hyvernat (1858-1941), who became the first professor appointed to the university when it was founded in 1887. The literature of the Copts was the subject of higher learning by far the closest to the mind and heart of Monsignor Hyvernat. An overview of the subject is presented in the present lecture. But it is not the lecture's sole topic. There is a certain complexity in regard to how the Copts and all that is Coptic fit into world history, all 5000 years of it, and clear definitions are not easy to find. The lecture takes on the challenge of presenting the matter clearly and distinctly-and at the same time comprehensively, yet also succinctly. It concludes with some observations on Hyvernat's life and work as seen through the author's personal lens.

\section{Keywords}

Ancient Egypt, Catholic University of America in Washington DC, Christianity, Coptic Literature, Copts (Coptic People), Egypt, Egyptian Christianity, Hyvernat (Henri), Hyvernat Lectures, Medieval Egypt

\section{Introduction}

What follows is the extended version of a lecture that was delivered on March 26, 2015, at 5:00 p.m., in St.

How to cite this paper: Depuydt, L. (2015). The Literature of the Copts and the Contributions of Monsignor Hyvernat to the Study of the Subject (Fourth Annual Henri Hyvernat Lecture). Advances in Historical Studies, 4, 320-335. 
Thomas Aquinas Hall on the campus of the Catholic University of America in Washington DC. The Acting Dean of the Graduate School of Arts and Sciences, Professor Claudia Bornholdt, Associate Professor of German, introduced the lecture. Professor Edward Cooke, the Chairman of the Department of Semitic and Egyptian Languages and Literatures, which organized the Hyvernat lectures, introduced the lecturer. Among the members of the audience was John H. Garvey, the President of the Catholic University of America. And so was the spouse of the anonymous donor who has been supporting the Hyvernat lectures.

After the lecture, certain audience members communicated to me the desirability of publishing the lecture. So here it is.

What follows is an original text from which an abridged version suitable in length for an evening lecture was selected for delivery at the occasion. The present text is about $40 \%$ longer than what was actually read. To retain the spirit of an occasion whose aim is to honor the memory of Henri Hyvernat, the lecture is presented here as it was read - though, as noted, in an extended version — and is not recast as a journal article with an extensive footnote apparatus and the like. However, the text has been subdivided into a number of sections, each with its own title. Greater detail about the subject of Coptic literature can be found among other places in Depuydt, 2010. Some excerpts from this lecture, addressed to a wider layman audience, will appear on pp. 49-57 of volume 41 of the November-December 2015 issue of the Biblical Archaeology Review (go to: www.biblicalarchaeology.org/coptic).

\section{Henri Hyvernat and the Catholic University of America}

The opportunity to address a learned audience at this august university on an occasion honoring the memory of one of its great men, or women, brings me the benefit of what the German poet of eternal fame, Friedrich Schiller, in one of his last letters, calls Mut und Stimmung (Fricke, 1955: p. 641). The letter is dated April 25, 1805. Schiller died on May 9, 1805. A dictionary translation of Mut und Stimmung as "courage and tone" sounds a bit technical. Perhaps, Schiller might have liked my rendition that the occasion brings "Yes, heart and, yes, spirit!"

Need it be said, the French-born Henri Hyvernat whose memory is being honored today was one of the select band of scholars that became the original faculty members of the Catholic University of America when it was founded in 1887 by the Catholic bishops of America. And is it necessary to observe that Professor Hyvernat was in fact the very first professor appointed to this new university? Is there further really a need to note that Father Hyvernat's service to the university spanning more than half a century from 1889 to his death in 1941, when he had been for some time the last surviving of the four original professors, earned him the epithet of Grand Old Man of this institution? Furthermore, does it need saying that Monsignor Hyvernat not only founded the department that organizes the present lecture and also the Institute for Christian Oriental Research that is closely associated with it but was also engaged in all sorts of ways with the growth of the university? "Oriental" in this case refers to the ancient and medieval languages and cultures of the Middle or Near East and Northern Africa.

In sum, it seems rather utterly needless to call to mind that Henri Hyvernat's life and work have left a deep lasting beneficent mark on the Catholic University of America.

\section{Henri Hyvernat, the Hyvernat Lecture, Coptic Literature, and Coptic Studies}

It was a bright summer day some months ago when my distinguished colleague Professor Edward Cooke conveyed to me the invitation to deliver the Fourth Annual Henri Hyvernat Lecture organized by the department that he chairs, the Department of Semitic and Egyptian Languages and Literatures. It took me only a couple of hours (I doublechecked) to not only gladly and gratefully accept the invitation but also to provide the title of my lecture. In a sense, the title provided itself right away. How so?

The literature of the Copts, mentioned in the lecture's title, was the subject of higher learning by far the closest to the mind-and, I am sure, also to the heart—of Hyvernat. It is more common to call the subject Coptic literature than the literature of the Copts. But then, this small literary license anticipates my intention to also speak quite a bit about the Copts as a people. Among notable Copts, many will remember the Egyptian Boutros Boutros Ghali, who was Secretary of the United Nations in the 1990s. He is a Copt.

A student of Coptic literature and all things Coptic is called a Coptologist or, sometimes-in England—also a Copticist. Scholars, including myself, would typically know Professor Hyvernat as a Coptologist. The Coptologist's field of study is called Coptology or also Coptic Studies. In fact, Hyvernat was America's first appointed Coptologist.

By convention, the focus of Coptologists is not on what it means to be Coptic in modern times or even premodern times. Coptologists are concerned mainly with ancient and medieval times. Likewise, the focus of a 
Roman historian is not on traffic conditions in modern Rome but on ancient Rome, the Rome of the Roman Empire.

Professional Coptologists are expected to be competent in independently analyzing various facets of the ancient and medieval history of the Copts. The main distinction is between more text-oriented Coptologists such as philologists and historians and more object-oriented Coptologists such as archaeologists and art historians. Coptologists will typically address topics of more recent date only in as far as these topics shed light on what came before. An example of such a topic is the rediscovery of the Coptic Church and the Coptic language in the Latin West from about the Renaissance onward.

It is customary for scholars to discuss their own research and not someone else's in a lecture, even in a memorial lecture. But as it happens, Coptic literature has occupied me too quite a bit, though less in recent years than before. In any event, to me, Professor Hyvernat is not only a colleague but also a fellow Coptologist. In fact, our career paths overlap in many ways. I will say a little more about this when, later in my lecture, I come to speak about Hyvernat's contributions to Coptic studies.

\section{Who Are the Copts?}

Nothing is more important to a line of argument than its beginning, as René Descartes aptly pointed out in his Discours de la méthode "Discourse on Method." Let my point of departure be the following self-evident reflection. One wonders how much awareness of, and knowledge about, the Copts and what is Coptic exists among the public at large. And yet, as a result of immigration since the late 1940s, there are several hundred thousand, and according to certain reports up to close to a million Copts or people of Coptic heritage in the United States, and tens of thousands more in Canada. Church attendance does not necessarily permit an accurate head count. Now really?

This means that as many as one in every 300 inhabitants in the US may be Coptic. If one includes all who know someone Coptic, one would expect a sizeable segment of the US population to have a notion of what being Coptic is all about. But as I noted before, one wonders how widespread basic familiarity with Coptic culture is.

\section{The History of the Copts and of What Is Coptic}

\subsection{The Complexity of the Topic}

Before turning to the subject announced in the title of this lecture, I will try to evoke the place of the Copts and of all that is Coptic in world history at some length and clarify a little bit what captivated Hyvernat so much throughout his entire life. As I already noted before, a major focus of this lecture will be on the Copts as a people rather than on their literature. That is because it is impossible to understand the latter without understanding the former. I hope to do all this without getting too didactic. Then again, there is a certain complexity in regard to how Coptic culture fits into world history, all 50,000 years of it, and clear definitions of the matter are not easy to find. Therefore, presenting the matter clearly and distinctly and-to the extent possible- succinctly, is an inviting challenge and I will attempt to take on this challenge. But again, I hope, without getting too stuffy. However, if stretch brings boredom, we will bring on jugglers and people cartwheeling and making funny faces and maybe fireworks - very small fireworks - to entertain you while I keep gesticulating.

My lecture is deliberately general. I realize that some members of the audience already know everything that I am going to say. But I hope that they will appreciate my own variation on the theme, my own spin as it were. There may still be quite a lot of detail to absorb all at once for those of you who may be new to the subject. So I encourage you to sample what seems most interesting on the menu. And anyhow, there is no exam at the end of the lecture. In addition, I am easy to find on the Internet. So I will be happy to entertain email enquiries.

The word "Coptic" has now been mentioned quite a few times. The time has come to define it.

\section{2. "Coptic": What's in a Name?}

The word "Coptic" has a certain exotic ring to it. And why not? The three occlusives $k, p$, and $t$ lend its pronunciation a certain robustness. Love that sound.

Before turning to the meaning of the word, something about its origin. The word derives from the ancient Greek word for Egypt, Aiguptos. In fact, the word "Egypt" itself also derives from Greek Aiguptos. So the $p$ and 
the $t$ of the word "Coptic" are the same $p$ and $t$ also found in the word "Egypt."

Incidentally, Greek for "Egypt," Aiguptos, may itself derive from an ancient Egyptian hieroglyphic name for the city of Memphis in Egypt. The afore-mentioned $p$ and $t$ would then be the $p$ and $t$ found in the name of the ancient Egyptian god Ptah, worshiped at Memphis, pronounced tah in English without the $p$ like the word "psychology." I refrain from discussing this etymology. But I have the impression that it needs a little more work.

So if "Coptic" and "Egyptian" are in a sense the same word, what is the difference? There are two differences.

First, "Coptic" and "Egyptian" came into English along different paths. "Egyptian” came directly from Greek through Latin. But the word "Coptic" came from Greek through Arabic through Latin. There was a detour through Arabic. So "Coptic" reflects to a degree the Arabic pronunciation of the Greek word "Egyptian." Why Arabic? That will become clear in a bit.

The Arabic equivalent of "Coptic" قبطى qubtiyy(un), or also qibtiyy(un). The Copts are called القبط al-qubt(u) or al-qibt(u), or also الاقباط al-'aqbāt(u). These Arabic words feature the two sounds $q \bar{a} f$ and $t \bar{a}$. They are so-called emphatic equivalents of $k$ and $t$. These two sounds do not occur in English and are hence a little difficult to pronounce for English native speakers who have not studied Arabic.

The second difference between "Coptic" and "Egyptian" pertains to meaning. "Egyptian" signifies everything Egyptian, and that includes all that is Coptic. "Coptic" signifies two specific facets of what is Egyptian. In other words, the term has two well-defined meanings. First, Coptic is the name of a language. It is now a dead language, more about this later. Second, Coptic is a synonym of "Christian Egyptian.” It is in this second meaning that the term "Coptic" is now known to the wider public.

\subsection{The Copts Today}

The following short history of the Copts and what is Coptic focuses mainly on antiquity and the early Middle Ages. But a brief note on Copts today.

Egypt has been in the news in the past couple of years. The Arab spring, and so on. It can hardly have escaped the attention of those who follow the news a little more closely that modern Egypt, a country of 80 million people or so, perhaps already more, is overwhelmingly Muslim. Then again, there is a Christian minority, the Copts.

The Copts, like Egypt in general, have also been in the news in relation to all the happenings in the Middle East in recent years. News about the Copts has not all been good. There was the recent murder by terrorists of 21 young Coptic men in Libya. I am afraid that we have not seen the worst of this kind of vicious brutality yet.

Nobody seems to know the exact number of Copts in Egypt. But about $10 \%$ of the population is a number often mentioned. That would be about eight million Copts, so definitely millions. And to put things in a broader perspective: the Copts are the largest Christian minority in that band of the world in which Islam dominates, all the way from Morocco to Indonesia.

The Christian church of the Copts is the Coptic Church. And at the head of the Coptic Church, just as of the Roman Catholic Church, stands a pope. Some of you may have read about the unusual way in which the Copts select their pope. In fact, there was an election a couple of years back. Three finalists are selected. The names are placed in a receptacle, I am assuming on pieces of paper (I do not know the exact details), and a little boy is asked to pick one out. The name picked is the new pope's. Devout Copts believe that this method allows for divine intervention in the selection process. The current pope is His Holiness Tawadros II. He is the Pope of Alexandria and the Patriarch of the See of St. Mark. Tradition has it that the Evangelist St. Mark was the first patriarch of Alexandria.

\subsection{The Copts and What Is Coptic in the Context of World History}

As a subject of learning, the history of the Copts presents to the scholar and philologist an intellectual delight shared by only a select few, like many of the rarefied fields of study plied by Hyvernat. It surely has done wonders for my feelings of superiority. Imagine, some of us are reduced to being chased by a million followers on Twitter. I am curious whether St. Thomas Aquinas would classify that as purgatory or as hell.

To fully appreciate the place of Coptic civilization in world history, it is useful and even necessary to consider the entire span of this history, all of it. History is by definition the period from which we have written sources. What comes before is prehistory. In that regard, history begins in Egypt and Mesopotamia with hieroglyphic and cuneiform sources about 3000 BC, 5000 years ago, give or take a couple of centuries. 


\subsection{The Ancient Roots of the Copts and of What Is Coptic}

The present focus is evidently on Egypt. Around 3000 BC, even a little before, the first hieroglyphs appear. But for a few hundred years, they hardly represent texts, just mostly isolated signs or words. Full-fledged hieroglyphic texts first emerge around 2600 to $2500 \mathrm{BC}$, roughly around the time when the great pyramids were built, even a little earlier. By the way, there are no hieroglyphic texts in the three great pyramids at Giza, by far the best-known ones.

From about 3000 BC, Egypt is ruled by dynasties of pharaohs bearing names like Sesostris and Ramses in the Greek sources. The Old Kingdom of the third millennium BC is followed by the Middle and New Kingdoms of the second millennium BC. The kingdoms are separated from one another by times of fragmentation, so-called Intermediate periods. The New Kingdom in the later second millennium is sometimes called the Age of the Empire because Egypt stood at its greatest expansion.

Over many hundreds of years, Egypt remained relatively unchanged, except for about 20 years around 1350 BC when the heretical king Akhenaten founded a kind of monotheistic religion and built a new capital at Amarna. Both his religion and his capital were abandoned at his death. The Amarna period is the single most remarkable period in all of Egyptian history, just by virtue of being so different.

Over the centuries, the Egyptian language changed. The five successive stages are called Old Egyptian, Middle Egyptian, Late Egyptian, Demotic, and finally Coptic. So Coptic is Egyptian. Or, Coptic is a stage of the Egyptian language in addition to being a synonym of "Christian Egyptian." The coexistence of the two meanings may seem confusing. But in practice, there is little cause for confusion, as I intend to show a little later.

Unlike the first four stages of Egyptian, Coptic is not written with hieroglyphs or cursive derivatives thereof but rather with Greek letters (Alpha, Beta, Gamma, Delta, and so on) expanded by a few characters taken from Demotic — an extremely cursivized variant of hieroglyphic writing — denoting sounds that Greek does not have. From a little bit of a distance, an ancient Coptic manuscript looks very similar to a Greek manuscript. Why write Egyptian with Greek letters?

From the seventh century BC onward, there were intermittent contacts between Egypt and the Greek world across the Mediterranean, often involving mercenaries or merchants. There was even a Greek colony called Naucratis on the Egyptian coast from about that time onward.

Then, in 332 BC, Alexander the Great of Macedonia conquered Egypt. After his death, in 323 BC, nine years later, his general Ptolemy started a dynasty of Greek immigrant kings almost all called Ptolemy lasting about three hundred years. The Rosetta Stone, the British Museum's top attraction, was composed in this period. It dates to 196 BC.

Consequently, Greek became an Egyptian language, as it were. In fact, it is not widely known that the oldest dated Greek text of all is found in Egypt. It is a graffito dating to 593 BC left by a mercenary on a military expedition into Nubia on the knee of one of the four Ramses colossi at Abu Simbel, the impressive rock temple that may be known to many of you.

Greek was spoken in Egypt mainly by a minority upper class concentrated for the most part in the cities and especially in the new capital built by Alexander himself: Alexandria. Alexandria was a Greek-speaking city. To this day, there is a sizable Greek-speaking population in the city of Alexandria. The last ruler of the Ptolemaic Dynasty was Queen Cleopatra. Now Cleopatra may well be the ancient Egyptian best known to the wider public. I will not detail her romps with Julius Caesar and Mark Antony. It is sufficient to note that, at Cleopatra's death in 30 BC, Egypt was conquered by Rome. Egypt became a province of the Roman Empire.

We are now getting closer to the Copts and what is Coptic. The story is getting warm, so to speak. Cleopatra died a little less than 30 years before the birth of Jesus of Nazareth, upon whose teachings the Christian religion is founded.

The term "Coptic" has been defined above as having two meanings: 1) as a synonym of "Christian-Egyptian"; 2) signifying a stage of the Egyptian language, the fifth and last. By the way, in meaning 1), "Coptic" is always an adjective. But in meaning 2), it is either an adjective or a substantive. Accordingly, "Coptic," as a substantive, always denotes the language.

It follows that the advent in world history of the Copts and what is Coptic involves developments in regard to 1) religion (see section 5.6 below) and 2) language and writing (see section 5.7 below).

\subsection{The Advent of the Copts and of What Is Coptic (I): In Terms of Religion}

When Christianity spread out from Palestine, it soon reached Egypt—which is quite nearby. There is no time 
presently to detail the expansion of Christianity in Egypt. Initially, in the first, second, and third centuries, the process was fairly gradual. But that all changed in the fourth century AD, in the early 300s. Christianity became a kind of state religion. The Roman emperor Constantine, who died in 337, promoted Christianity. And he was baptized on his deathbed, as was not uncommon in those days.

In the beginning of the fourth century, the religious landscape in Egypt was still rather diverse. But by 100 to 150 years later, say by about AD 450, Christianity had become the religion of the majority of Egyptians.

Thus, over the course of four centuries, the 3000-year old ancient Egyptian religion had to make place for Christianity. Only isolated pockets of the old religion in the deep south of Egypt survived. And in the sixth century AD, the Byzantine emperor Justinian ordered even those closed. Egyptian religion cannot have survived much beyond $\mathrm{AD} 550$ if at all.

\subsection{The Advent of the Copts and of What Is Coptic (II): In Terms of Language and Writing}

From the first century AD to the fourth to fifth century AD, over the course of four centuries or so, Egypt became a Christian country, a significant development. But there was a second and simultaneous significant development. It involves the decline of ancient Egyptian hieroglyphic writing and its cursive derivatives. But that does not mean that the spoken Egyptian language declined.

The dynamics of this second development are not fully clear. One contributing factor appears to have been the following. When the Romans arrived in Egypt in full force at Cleopatra's death in 30 BC, it seems as if they felt that they could deal with only one more language, Greek, which many educated Romans studied and even spoke. But dealing with Egyptian as well was a little too much. One more language was more than enough. Under Roman rule, there was much pressure to write all sorts of documents in Greek and not in Egyptian.

The Egyptian stage used at the time was Demotic, which is - as was already noted - the fourth of the five stages of Egyptian, the one immediately preceding Coptic. Demotic is already a lot like Coptic. But a sort of chasm separates the two, and that in two respects. First, Demotic is written in a rather hard to read cursive variant of hieroglyphic writing, whereas Coptic is written mainly with Greek letters. Second, Demotic gives expression to native Egyptian culture, whereas Coptic gives expression to Christian culture.

In any event, in the late second century $\mathrm{AD}, \mathrm{AD} 170,180,190$, there was a significant decline in the quality of hieroglyphic writing. Hieroglyphs otherwise offer so much opportunity for artistic expression. But they now started to look rather very crude and did so for another two centuries before vanishing entirely. There are no dated examples of hieroglyphs beyond AD 400. And cursive variants of hieroglyphic writing like Demotic did not last much longer.

For a couple of centuries, the 100s and 200s AD, the Egyptian language was much less written even if it was still spoken by the vast majority of Egyptians.

Since Egyptian and Greek were used side by side in Egypt from the seventh century BC onward, it does not come as a surprise that there are occasional but rare attempts to write Egyptian with Greek letters. These attempts are now called Pre-Coptic.

Then, roughly around AD 200, maybe a little earlier, it became customary to add characters from Demotic to the Greek alphabet to signify sounds not existing in Greek. Writing Egyptian with this enhanced Greek alphabet is now called Old Coptic, as distinct from Pre-Coptic, which does not exhibit the enhancements.

In general, the writing and language situation is complex in the first couple centuries of our era in Egypt. The complexity might seem a little overwhelming to anyone new to the matter. The sources are not very revealing as to exactly what happened. But I do not want to sound overly pessimistic. There is still hope that closer scrutiny in the years ahead will yield a more precise picture.

One thing is clear, however. At some point, there was this bolt out of the blue, as it were. All of a sudden, seemingly coming out of nowhere, sometime roughly around AD 300 or a little later, there emerges a fully developed, fully standardized way of writing Egyptian with Greek letters supplemented by six or seven characters taken from Demotic. That is what we now call Coptic, as distinct from Pre-Coptic and Old Coptic. After a lull of a couple of centuries, stable and solid conventions returned to the writing of Egyptian.

At the same time, the spoken language, of which the written language is just a reflection, had evolved as well.

\subsection{The Jewish Creators of Coptic}

The creation of Coptic involved 1) the creation of a writing system and 2) the selection of certain specific idioms 
(since each region had its own dialect). My overall impression is that there is something vaguely artificial about written Coptic, I suspect the result of scribes consciously selecting certain expressions at the exclusion of others to translate the Bible into Egyptian, a process that is not fully natural. The natural use of a language ought to be entirely unconscious. Also, just consider the use of so many Greek words in Coptic, including many particles such as "but" and “for." I am not sure that there were ever many Greek words to be found in the Egyptian spoken in the streets of Egypt, if any.

It is not known who the creators of Coptic were. It is often assumed that Coptic was developed to facilitate the evangelization of the Egyptian crowds. Presumably, hieroglyphic writing was just too difficult to be accessible to many. According to this assumption, the spread of Christianity precipitated the decline of hieroglyphic writing just as much as it precipitated the decline of ancient Egyptian culture and religion in general.

However, a lone voice dissenting with the prevailing assumption that Coptic was designed as a kind of missionary tool was the Belgian Coptologist Louis Théophile Lefort's. And I may well have been alone so far in explicitly aligning myself with Lefort in print. Then again, my teacher Hans Jacob Polotsky (1905-1991) was one of the very few ever even to discuss Lefort's view and his discussion does not reveal any hint of disapproval (Polotsky, 1971: p. 211).

Lefort pointed to reasonable arguments indicating that the Coptic Old Testament was translated before the New Testament. In other words, there was a time when the Coptic Old Testament existed and the New Testament did not. Who would be in need of only the Old Testament? That is easy to answer, Lefort thought: Jewish scribes of course. In sum, nothing is more typical of Coptic than its Christian character. But it may well have been a Jewish creation. Then again, Lefort's thesis does not preclude that Coptic was picked up later for the cause of evangelization.

By the way, the Coptic Old Testament is not translated from the original Hebrew Bible but from the Greek translation of the Hebrew, which is called the Septuagint. In fact, Egyptian Jews did not speak Hebrew in daily life. It is generally assumed that they mostly spoke Greek. But if Lefort is correct, some if not quite a few of them spoke Egyptian. It is a possibility that generally has not drawn much attention: Jews speaking Coptic. Lefort plausibly locates Coptic-speaking Jews in southern Egypt, far from Greek-speaking Alexandria.

\subsection{The Coptic Language as a Multifaceted Challenge}

Coptologists have many varied interests. Mine are presently primarily in the language and in the history of Egyptian from its very beginning to its very end, that is, linguistic and philological. No language is attested over a longer period of time. May I recommend Coptic to the philologically minded as a wonderfully multi-faceted challenge?

In one dimension, it is the last and best-known stage of Egyptian, which has the longest attested history of any language.

In another dimension, many texts have either been translated from Greek into Coptic or from Coptic into Arabic or Ethiopic (or through Arabic into Ethiopic), or both.

In yet another dimension, many Coptic texts have versions or close parallels in a diverse range of Christian Near Eastern and North African languages belonging to several language groups other than Coptic itself, including Armenian (which is Indo-European), Georgian (which is Caucasian), and Arabic, Aramaic, Ethiopic, and Syriac (which are Semitic).

And in yet one more dimension, Coptic is the language of one of the historically most important versions of the world's most read book, the Bible.

At first sight, the Coptic language may seem to be nowhere. But on closer inspection, it appears to be everywhere.

\subsection{What Did Copts Call Themselves and Their Language When Speaking Coptic?}

Two evolutionary patterns have been described above. Both occurred roughly simultaneously some time in the two centuries lasting from AD 200 to AD 400. First, Egyptians started writing their language with mainly Greek letters. Second, Egyptians became a predominantly Christian people. It is not clear what the exact relation is, if any, between these two developments.

Egyptian Christians are called Copts; the Egyptian language written mainly in Greek letters, Coptic. But Coptic-speaking Egyptian Christians, when speaking Coptic, never called themselves Copts, nor their language Cop- 
tic. Rather, they referred to themselves in Coptic as the "people of Kēme (KAY-muh)." Kēme means "Black (Land).” And they called their language the "language of the Black Land.” Why black?

The geography of Egypt is quite peculiar. As far as the inundation of the Nile River and irrigation reaches, the land is dark and fertile, black so to speak. Hence, Black Land as the ancient Egyptian name of Egypt. The desert or so-called Red Land begins right were irrigation ceases. The dividing line between the Black Land and the Red Land could not be sharper.

So who first called the Copts Copts and the Coptic language Coptic? I am still located around AD 400 and would have to anticipate something that happened a few centuries later. So I will try to bridge the gap first. But let it already be noted that it was speakers of Arabic who first used the word "Coptic." Who were these speakers of Arabic? The question is answered further below.

\subsection{The Christian or Coptic Era in the History of Egypt}

The fourth century constitutes the beginning of what may be called the Christian Era in the history of Egypt, or also the Coptic Era because "Coptic" can mean "Christian Egyptian." The history of Egypt is about 5,000 years long, from the earliest hieroglyphs to modern-day Egypt. The Coptic Era lasts one tenth of that, about 500 years, from the fourth century AD to the ninth century AD. If one took a long walk anywhere in Egypt in those centuries, from the 400 s to the 800 s, one would find the landscape dotted with churches. It would be a little bit like walking around in medieval France and in fact in much of modern Europe, in which each village is gathered around a church and most cities have several if not many church towers. Before the Coptic Era, one would have seen ancient Egyptian temples everywhere. After the Coptic Era, minarets and mosques became predominant.

Egypt had been part of the Byzantine or East Roman empire since AD 395, when the emperor Theodosius at his death at age 48 bequeathed the East of the Roman Empire to his son Arkadios and the West to his son Honorius. Therefore, Egypt was effectively ruled from Constantinople, current-day Istanbul, also called Byzantium from AD 395 onward until around AD 641. What happened around AD 641 is described further below.

Everyone is familiar with the terms "antiquity" and "Middle Ages." But where does the former end and the latter begin? According to some definitions, the Middle Ages begin as early as with the Roman emperor Diocletian around $\mathrm{AD} 300$; according to others, as late as with Charlemagne around $\mathrm{AD} 800$. By this reckoning, the Coptic Era described above might equally well be either entirely part of antiquity or entirely part of the Middle Ages. And so in fact could Coptic literature, as will become clear further below.

\subsection{Monophysitism}

The history of the Copts is complex, involving various languages and religions. And I have even bypassed the intricacies of the history of early Christianity involving schisms, denominations, sects, councils, and so on. The religious historical event that was perhaps most significant to the history of the Egyptian or Coptic Church in the early centuries of its existence was the Council of Chalcedon of AD 451. At that Council, the dominant patriarch located in the capital of Constantinople and the patriarch of Alexandria parted ways. How so?

Most of the Coptic Church adopted the doctrine that is called Monophysitism, from Greek $\mu$ óvo $̧$ monos "one

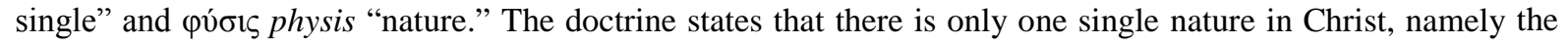
divine nature. The Roman Catholic and Greek Orthodox Churches hold that there are two natures in Christ. In Monophysitism, Christ is not really human in any way. A simple example.

In the Gospel of Mark, chapter 5 verse 27, a woman touches Jesus’s garment. At verse 31, Jesus asks "Who

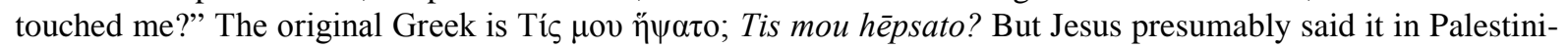
an Aramaic. The Syriac version, Man-u qrev lì?, is Aramaic alright but it is translated from the Greek. So we cannot really be sure about Jesus's exact words.

Monophysite commentators in catenae, that is, chain commentaries on the Bible, will note that Jesus really knew the answer to his own question because he is divine only and therefore omniscient. He was playacting, as it were. Roman Catholic and Greek Orthodox doctrine holds that the two natures, divine and human, coexist. And if one cannot understand how Jesus could not have known who touched him, then this is deemed a mystery.

In recent decades, there have been efforts at theological rapprochement between the Roman Catholic Church and the Coptic Monophysite church and there is a belief even on the highest level that the respective doctrines can be reconciled. I am not a theologian. Still, Jesus knew whether someone touched his garment or he did not. One cannot have it both ways. I have not looked into the matter. 
What ended the 500-year Coptic Christian period in Egypt lasting from the fourth century to the ninth century? Only a few centuries after the arrival of the new religion of Christianity had brought deep change to much of the inhabited world, a second new religion brought equally deep change to the Middle East and North Africa and beyond. Gradually, in vast areas that had evolved from minority Christian to majority Christian, Christianity found itself returning to minority status after just a couple of centuries. This is the origin of the Christian minorities in Iraq and Syria and other Middle Eastern countries, minorities that are also in the news these days, not in the least because of the threats that they face. The new religious movement was Islam (pronounced isl $\_m$ in Arabic).

\subsection{The Advent of Islam in Egypt}

On June 8, AD 632, the Prophet Mohammed died. Devout Muslims do not mention the name of the Prophet without adding the eulogy șallā llāhu 'alay-hi wa-sallama "May Allah pray upon him and protect him!” About 22 years earlier, around 610, he had the first of many annunciations. And in this way, the Koran (Arabic Qur'ān, with that emphatic $k$ again, as in qubtiyy, which is Arabic for Coptic) was revealed to him. Certain traditions have it that Mohammed could neither read nor write. But he recited the Koran by divine inspiration. And that is what Koran means: "the recited word" (the word that is read, but in this case by someone who cannot read). Two years after his death, his caliphs and their armies began conquering much of the Middle East and North Africa. "Caliph,” خليفة Khaliffa in Arabic, means “successor.” Around AD 641, Egypt was conquered too.

The coming of Islam to Egypt is the beginning of the long process of the Islamization of Egypt, that is, the conversion of Egypt to Islam, a process that in the end reduced the number of Christians in the Egyptian population to what may be about $10 \%$. It is a process of which a more detailed history still needs to be written, if the extant sources allow it. And I would like at this point to take the opportunity at this point to recognize my distinguished colleague Father Sidney Griffith, professor emeritus and standard-bearer of the department organizing this lecture, here present, for his profound researches on this academic topic, with special focus on Syria and environs, and for his widely acclaimed efforts in interfaith Christian-Muslim dialogue.

\subsection{Birth of the Term "Coptic"}

The Muslim conquerors of Egypt spoke Arabic. What they found upon arriving in Egypt around AD 640 was a Christian country in which a minority upper class spoke Greek and did business in Greek and a majority lower class who spoke a stage of Egyptian that we now call Coptic but who also did part of its business in Greek.

So what are the precise circumstances in which the Copts came to be called Copts and the Coptic language Coptic? The details are not a little murky. I had never myself addressed the question. And an adequate answer is not easy to find. The sources are not necessarily very yielding or have been insufficiently well researched. It seems as if the surface has not yet been scratched with regard to the matter at hand. So I collected some of my own provisional observations regarding the matter.

About one fact there can be no doubt. The birth of the term Coptic cannot antedate the Muslim Conquest of Egypt around AD 641 because the term is an Arabic form of the Greek word for Egypt.

But where was the Arabic term "Coptic” first heard or seen in Egypt? Some years ago, the Jesuit Pierre du Bourguet suggested that it first appeared in Arabic acts from the conquest onward (du Bourguet, 1991: p. 599). But he acknowledges that no textual evidence to this effect has been found. One might ask: Why necessarily in written acts? Why not in the daily speech of immigrant speakers of Arabic? In that case, the exact circumstances of the genesis of the term would forever remain inaccessible to empirical observation because the records of daily speech are evidently forever lost.

Arabic speakers used the term "Coptic" to refer to both 1) a language and 2) a people. It seems reasonable to assume that this dual usage goes back to the earliest years after the Muslim conquest.

First, language. How did the term "Coptic" come to denote the last stage of the Egyptian language? This question seems easy to answer. There were two main languages in Egypt when the Arab conquerors arrived, Greek spoken by an upper class minority and native Egyptian spoken by the majority. Evidently, Greek must have been called Greek and there is no way that it could have been referred to as Egyptian in any form or fashion. All this left the term "Coptic," qubtiyy, as the natural designation of the native Egyptian language in its final stage. 
But what about the other meaning of "Coptic," as designation of a people? Adequate statements regarding the matter are not easy to find if they at all exist. When Arabs conquered Egypt, what did they find? They found a nation that was predominantly Christian. All traces of the native Egyptian religion must have vanished by then. I am not aware of any mention of fully active so-called pagan temples in Arabic writings from Egypt.

What is more, the Arabs found two main denominations of Christianity, each led by a patriarch. One denomination consisted of the Monophysites who had split off from Constantinople. Its patriarch was at the same time a pope. Monophysites presumably included many or most if not all Egyptian-speaking Christians but also Greek-speaking Christians. While the Monophysites had split from the church of Constantinople, Egypt was still part of the Byzantine Empire whose capital was located at Constantinople. Greek was therefore the language of government. While Monophysites might have perhaps preferred using Coptic, the use of Greek was necessary if they wanted to communicate with government officials.

The other denomination consisted of the Christians that had remained in union with Constantinople or Greek Orthodoxy. They were probably for the most part Greek-speaking.

The main contact of the Arab conquerors must have been the Greek-speaking upper class that was in power, one would think.

There is a report that the general who led the conquest of Egypt, 'Amr ibn al-'Āṣ met the patriarch of the Monophysites, Benjamin I, and recognized him as the sole representative of the Egyptian people (Müller, 1991: p. 376). But even if Benjamin I may have been born as a native Egyptian speaker (we know that he was born in a village and Greek speakers congregated for the most part in the cities), he would presumably have used Greek in communicating with the general through interpreters.

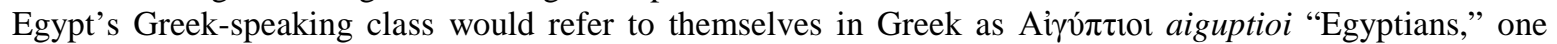
would think. If someone identifies him- or herself as British or Canadian, it seems only natural for someone else to refer to them in the same way. Most Arabic words consist of three consonants. It would therefore only be normal for Arabic speakers to shorten aiguptioi to gupti or the like. Arabic of the Arabic Peninsula did not have the voiced occlusive as heard in English "ghost.” But emphatic $q$ is close. But I do not want to push this. We do not know the exact phonetic details.

The Egyptians at the time were almost all Christians. The term qubtiyy, which became "Coptic" in English, therefore became permanently associated with Christian Egyptian. Accordingly, once the term was established with this meaning, I cannot see how Egyptian Muslims could ever have referred to themselves as Copts.

At some point, it became common to call Christians who had remained in union with Constantinople "Melchites," a word derived from the Arabic word for "king," ملك malik. The ruler, or king, or emperor, of Egypt was after all located in Constantinople. At the same time, it became possible to use the term "Coptic" exclusively for the Monophysites. This is a little confusing as the term can also denote other Egyptian Christians, including the Melchites. In fact, since the nineteenth century, there are now also Roman Catholic Copts, 100,000 and up (I have not done any research), and Protestant Copts.

Incidentally, modern Egyptians call Egypt mișr or more colloquially, mașr. Mișr was originally a name for Cairo, now the capital of Egypt. Cairo was founded only in the tenth century AD.

I have deliberately focused on some observations of the early years of the use of the term "Coptic," because it was a matter that I had not quite thought out in all its consequences. So I took the occasion to cover some new ground. Evidently, the final word has not been said about the matter.

\subsection{The Copts and What Is Coptic in the Past Thousand Years: Two Developments}

Two main developments characterize the history of the Copts in the past millennium.

The first development pertains to religion. For a couple of centuries after the Conquest, the Christians remained in the majority. But the pressures started rising in the ninth century AD. There were quelled revolts, fiscal and linguistic pressures, and even persecutions. It is not easy to quantify the rate of conversion from Christianity to Islam. But it seems as if, by the eleventh or twelfth centuries AD, the Copts had become a minority.

The second development pertains to language. The number of speakers of Coptic Egyptian steadily declined. By perhaps about the twelfth or thirteenth centuries AD, only few can have been left. I wonder whether there were any at all left by AD 1500. Coptic, and therefore also ancient Egyptian in general, must have been a dead language by then. Most everyone now spoke Arabic, as all Egyptians still do today. Reports of pockets of speakers of Coptic surviving beyond AD 1500 need to be treated with utmost caution.

Then again, Coptic remained widely used, as it does to the present day, in the liturgy. However, no new texts 
were written in it. There was still new literature being produced. But it was now written in Arabic. Moreover, much literature originally written in Coptic was translated into Arabic. 1) Coptic translated into Arabic and 2) Egyptian Christian literature originally written in Arabic are the two branches of what is called Coptic-Arabic literature. In the term "Coptic-Arabic," Coptic is evidently understood as referring to a people and not to a language.

\subsection{The Inability to Confuse the Two Meanings of the Term "Coptic"}

One issue mentioned before can now also be resolved, the potential for confusing the two meanings of the term "Coptic" as referring to both a language and a religion. I have not seen the matter addressed anywhere. Upon closer inspection, it appears that historically speaking there has in fact been little cause for confusion. A distinction applies between an early phase, a middle phase, and a final phase.

In the early phase, most Egyptians were still Christian and most Egyptians still spoke Coptic. Christian Egyptians and speakers of Coptic were for the most part the same people. No cause for confusion here.

In the middle phase, as the Christian community decreased in size and the speakers of Coptic did too, the overlap between the two groups must have been for the greater part retained. No cause for confusion here either.

Then, in the final phase, when Coptic died out as a spoken language, its use was restricted to the liturgy of a minority of Egyptians. Under those circumstances, how many inhabitants of Egypt were still aware of what Coptic was as a language. And how much occasion was there to refer to the Coptic liturgy? Liturgy is not necessarily a daily topic of conversation. Therefore, in the final phase, for most people most of the time, the word "Coptic" had just one meaning, "Christian Egyptian."

I note in the margin that it has been common for Christian Egyptians to embrace Pharaonic and hieroglyphic civilization much more eagerly than Muslim Christians. At Coptic fairs held in Coptic parishes across the U.S.A., and I presume elsewhere, it is possible to find all kinds of Egyptianizing artefacts on display and on sale. The Coptic language does after all descend from hieroglyphic Egyptian. And Christian Egyptians presumably descend mostly from the original inhabitants of Egypt while Muslims presumably descend from both converts and immigrants. Also, in much of Islam, there is a strong resistance, to say the least, to anthropomorphic representations of anything that is divine or saintly.

\section{Coptic Literature}

\subsection{How Much Is There?}

The eminent Swiss Coptologist Rodolphe Kasser, who recently passed away, made a stab at the question (Kasser, 2006: p. 391). I do not know how he did it. He counted 40 million symbols, almost all letters. It is difficult to compare the lengths of words in Coptic with the lengths of words in English. But let us take English to obtain a rough idea. A doctoral dissertation at the University of Cambridge, England, should be about 80,000 words, I read somewhere-not a big book, but still a book, maybe 200 pages or so. Let us say that there are about five letters to a word on average in English. That would be 400,000 letters in each dissertation. Consequently, the totality of Coptic literature would encompass about 100 of those dissertations. One can sort of picture them on a shelf, 10 times 10 books. To play it quite safe, even if quantifying the matter remains a little elusive, one might say that there many fewer than 500 books of Coptic literature, but considerably more than 20 books.

\subsection{When Was It Written?}

Coptic literature in Coptic was created for the most part in the period from AD 300 to AD 800. Not much new literature was composed later on. That means that, by one afore-mentioned definition about the beginning of the Middle Ages, it was composed for the most part in Late Antiquity; by another afore-mentioned definition, for the most part in the Middle Ages.

\subsection{The Principal Characteristics of Coptic Literature}

Seven eight years ago, the publishing house Wiley Blackwell decided to produce a twelve thirteen hundred page "Companion to Ancient Egypt," a kind of manual for advanced students and professional Egyptologists. The editor, Alan B. Lloyd, Professor Emeritus at the University of Swansea, Wales, asked me to contribute the 
chapter on "Coptic and Coptic Literature." I accepted and believe my contribution to be a halfway decent up-to-date account of the subject (Depuydt, 2010). I have naturally drawn on this account to provide the present bird's eye view of the history of the Copts and of Coptic literature.

As to Coptic literature's most striking characteristics, I came up with 14. A distinction applies between six (6) external characteristics, which do not pertain to the contents of the texts, and eight (8) internal characteristics, which do. I describe them here in summary fashion. For all details, I refer to the afore-mentioned article.

\subsection{External Characteristics, Not Pertaining to Contents (6)}

Three of the six external characteristics pertain to the physical medium of transmission and three to the language or the linguistic vehicle.

Those pertaining to physical medium of transmission are as follows. First, Coptic literature was written in Antiquity and the Middle Ages on papyrus, parchment, or paper, all three materials. By contrast, pre-Coptic Egyptian literature had typically been written on papyrus. Second, Coptic books are all in codex format. "Codex" is just the name for the modern book format when the book is handwritten. By contrast, pre-Coptic literature had been typically inscribed on papyrus rolls or scrolls tied with a string. And third, Coptic literature stands out by serving as the contents of many of the world's oldest extant books in codex format. A confluence of circumstances has produced this third characteristic of Coptic literature.

The external characteristics pertaining to language are as follows. First, there is the high frequency of Greek loan words in Coptic. Second, the fact that Coptic literature is preserved in several dialects stands in sharp contrast with the literatures of other Christian Near Eastern communities such as the Armenian, Ethiopian, Georgian, and Syriac churches, which are conveyed by a single dialectic idiom. Third, Coptic is by far the best-known stage of the Egyptian language.

\subsection{Internal Characteristics, Pertaining to Contents (8)}

Of eight internal characteristics pertaining to contents, five are what I would call distinctive and three are what I would call unique. The distinctive characteristics are those that set Coptic literature apart from many other literatures. They are as follows.

First, much of Coptic literature has been translated from Greek. Second, Coptic literature is overwhelmingly Christian. Third, Coptic literature is for the most part of the popular kind. It consists mainly of types of text that one might hear read in church on Sundays. Intellectually sophisticated discourse of any type, including Christian, took place in Greek. Fourth, many of the Coptic manuscripts that have survived are Biblical. In fact, almost all Christian literature in Coptic is steeped in Biblical lore and phraseology. Some homilies are mere patchworks of Biblical citations with minimal commentary. And fifth, Coptic literature composed after AD 451, the date of the Council of Chalcedon, is occasionally written in defense of the doctrine of Monophysitism.

The three (3) unique characteristics are those that are hard to find in many other literatures. They are as follows.

First, a sizeable component of Coptic literature is Manichaean. Second, another sizable component of Coptic literature is Gnostic. Coptic sources have hence provided essential documentation for the history of these two religious movements. Neither Manichaean nor Gnostic doctrine is Christian. But both share much with, or are influenced by, Christianity-Gnosticism more so than Manichaeism. And third, a religious movement to which Coptic literature makes a vital contribution does belong squarely in the Christian tradition, namely monasticism. Egypt is widely considered to be the cradle of the worldwide movement of Christian monasticism.

\subsection{Main Types}

If one disregards what little poetry and what few medical and mathematical texts and church canonical texts survive, then aside from the afore-mentioned Manichaean and Gnostic texts the vast majority of surviving Coptic texts belong in church on Sunday. Three things matter most in church: the Book, the Lesson, and the Rite. The Book and the Lesson together form the principal contents of the service and the rite or liturgy serves as a kind of glue. Accordingly, the bulk of Coptic literature consists of three main types.

First the Book and what is closely associated with it. The Book is evidently the Bible. The Holy Mass con- 
tains Bible readings.

Second is the Lesson. The need is for additional edification of churchgoers. The sermon serves this purpose. Many sermons and sermon-like texts have been preserved. There are two main types. The first main type concerns interpretation of the Bible, making the Book more relevant to the lives of believers. The second main type focuses on holding up an exemplary Christian as a model providing inspiration or being worthy of emulation, generally called saints. A special class of saints consists of martyr saints, those who died violently for their faith in the early days of Christianity when it was persecuted, mainly by the Roman authorities. Among the martyrs are a number of soldier martyrs: soldiers in the Roman army who converted to Christianity, swore off the pagan gods, and were martyred for their faith.

The Book and the Lesson could not by themselves make up an entire service. Third is the Rite, consisting of liturgical texts. The need was for connective material in the forms of prayers and similar texts, not only for the masses but also for the daily worship routines of the monks.

\section{The Life and Work of Henri Hyvernat}

\subsection{A Personal Perspective}

As announced in the title, I wish to speak about Henri Hyvernat's contributions to Coptic Studies. But I am not going to read down his CV. His accomplishments are evident. Hyvernat studied and taught all kinds of ancient languages. Among his earlier publications were a lavish Coptic paleographic album and an edition of Coptic martyrdoms.

I note here that Hyvernat's first name is in fact spelled with a $y$ on his French birth certificate and that he learned English quite well already as a teenager, even translating an English novel into French as a gift for his mother (Blanchard, 2015: 1 note 5, 2). These facts seem like a prefiguration of his assuming a professorship at an anglophone university at age 31 .

For the remainder of the lecture, I would like to view Hyvernat's life and work through a personal lens. I am again inspired by Schiller who, in the afore-mentioned letter, says about his engagement with history that alles auf die Art ankommt, wie ich den Stoff nehme, und nicht, wie er wirklich ist "It all comes down to how I take on the subject matter, and not, how it really is." And in another letter, he differentiates his own attitude to literature from Johann Wolfgang von Goethe more or less in the same way. That may explain why I am not the only person who likes reading the poetic Schiller a lot more than the poetic Goethe.

The reason for the personal perspective is that it seems almost uncanny in how many ways my own life has crossed paths with Hyvernat's.

\subsection{The Catholic University of America, the Catholic University of Louvain, and Henri Hyvernat}

Let me begin by noting that my bachelor and licentiate alma mater, the Flemish- or Dutch-speaking Catholic university located in the city of Leuven (English: Louvain) in Belgium's region of Flanders, now styled as KU Leuven, as well as the French-speaking Catholic University located in Louvain-la-Neuve in Belgium's region of Wallonia, are sister institutions of the Catholic University of America. In Hyvernat's time, there was just one Belgian Catholic university (I refer to it as the Catholic University of Louvain), located in Leuven, originally French-speaking, but from the 1930s onward both French-speaking and Flemish-speaking, until the university split into two in the 1960s and 1970s, a process that I witnessed myself, in that I took many classes in a Flemish town in a building in which most classes were conducted in French, until 1978 or so. I remember the banner hung on that building when the last French-speaking students left, exclaiming: Le coq a chanté "The rooster has crowed (sung)."

The Catholic University of Louvain, the oldest in the so-called Lowlands, founded in 1425, served as a model when the Catholic University of America was founded.

Now, in the early twentieth century, for about forty years, up to 1940, the year before Hyvernat's death, the presidents or rectors or rectores magnifici of the Catholic University of Louvain, were in succession two Coptologists, Adolphe Hebbelynck and Paulin Ladeuze. What other university can claim such a distinction? These were Hyvernat's fellow Coptologists for much of his life.

[Note: Another interest of Hyvernat's early in his career was Syriac literature. It came to my attention after 
the lecture that a scholar of Syriac, Jan-Baptist Abbeloos, a native of the village of Hooik in Belgium, was rector of the Catholic University of Louvain immediately preceding Hebbelynck and Ladeuze, namely in 1887-1898. That fact extends to more than half a century, almost completely overlapping Hyvernat's professional career, the period in which presidents of the Catholic University of Louvain were specialists in the fields that were by far the closest to Hyvernat's.]

In those same years, in 1903 to be precise, Hyvernat helped found a scientific series aimed at publishing ancient and medieval Christian North African and Near Eastern writers, the Corpus Scriptorum Christianorum Orientalium. The series, in which many hundreds of volumes have appeared, is now jointly owned by the Catholic universities of Washington, Leuven, and Louvain-la-Neuve.

This personal association of mine with Hyvernat may be a little tangential. But another association is all but tangential.

\subsection{Pope Pius XI, J(ohn) Pierpont Morgan, J(ohn) P(ierpont) Morgan, Jr, the Morgan Library and Museum's Coptic Collection, and Henri Hyvernat}

For two to three decades, Professor Hyvernat devoted much study to the Coptic manuscripts kept at the Pierpont Morgan Library and Museum in midtown Manhattan. The celebrated English Coptologist Walter Ewing Crum, author of the standard Coptic dictionary, called it "the largest and, in some ways, the most important of extant collections, ... a body of texts unparalleled for completeness, if not for variety."

The bulk of these manuscripts were discovered in Egypt in 1910 at the ruined site of a monastery dedicated to St. Michael and they were soon after acquired by J(ohn) Pierpont Morgan (1837-1913), the financier and philanthropist, and the patriarch of the Morgan family, whose name many will know from the financial institutions Morgan Stanley and JPMorgan Chase. Hyvernat served as a personal consultant to the patriarch, who died in 1913 after having single-handedly saved the entire US financial system in 1907. His friends called him "Pierpont.” After Pierpont's death, Hyvernat’s dealings were with his son J(ohn) Pierpont Morgan, Jr. (1867-1943), whose friends called him "Jack."

The manuscripts arrived in New York but were soon sent back to the Vatican for restoration. They were received at the Vatican Library in the early teens of last century among others by the Vice Prefect Achille Ratti, the later Pope Pius XI, under whose papacy (1922-1939) Vatican City became independent. Ratti was a librarian. I like to think that his engagement with Coptic manuscripts tipped the balance in his favor at the conclave in 1922 and that the word "Coptic" was heard being whispered among the red-robed cardinals in the Sistine Chapel. But then, I am not sure.

Hyvernat worked for many years on the Morgan Coptic manuscripts, in the teens and twenties and into the thirties of last century, and he finished a catalogue in typescript. But by that time, he was too much stricken by illness and the catalogue as a result remained unpublished.

About forty years later, in 1987, I visited the Morgan Library for the first time together with my dissertation advisor at Yale University, Bentley Layton, who had just published a catalogue of Coptic manuscripts kept at the British Library. It was decided that the cataloguing would need to be started $a b$ ovo "from scratch," involving all independent observations. But obviously, the foundational work by Hyvernat on the collection much benefitted my own work. The results were a catalogue raisonné of the collection submitted as my Yale Ph.D. dissertation in 1990 and published in 1993.

It is worthy of note that one of my three dissertation committee members was the Jesuit Father David Johnson, who passed away a couple of years ago. He was a professor at this institution and a successor to Hyvernat in certain subjects including Coptic. I was his guest at Jesuit House for several days in the late 1980s when I visited the Institute for Christian Oriental Research to examine the Hyvernat legacy in connection with my dissertation. And I would like to invoke his blessed memory at this occasion. [Note: I learned during my visit to CUA for the purpose of the Fourth Hyvernat Lecture that Jesuit House, or Carroll House, appears to have been disbanded.]

\subsection{A Walk along Memory Lane: The Louvain University Library}

I conclude my brief, personal, biographical appreciation of Henri Hyvernat by trying to make my way back from the Catholic University of America to the Catholic University of Louvain in a walk along memory lane.

Most of the Coptic manuscripts discovered in 1910 at the afore-mentioned monastery of St. Michael ended up at the Morgan Library. But not all. A few were acquired by the University of Louvain. They include a much 
damaged copy of the Coptic version of the first two books of the Pentateuch. The well preserved companion volume containing the last three books is at the Morgan Library.

Then, on May 17, 1940, at the beginning of World War II, the Louvain Library was infamously bombed, presumably because of the strategic potential of its tower. There was a fire and the Coptic manuscripts in question were destroyed. Hyvernat died the next year, in 1941, and it would be worthwhile to establish whether he had become cognizant of the sad fact because he knew the manuscripts well. Hyvernat was an inveterate record keeper, witness the 38 meters or 57 boxes of archives kept at the Mullen Library and more materials at the Institute for Christian Oriental Research. The answer may be found somewhere in those archives. [Note: I learned from Dr. Monica Blanchard via email in the course of preparing for this lecture that the surviving records provide no answer to this query.]

Now, as for the Louvain University Library, it had been destroyed much more thoroughly in World War I. Then, from 1923 to 1928 it was rebuilt with American funds. When the Library was inaugurated on July 4, 1928, it had been adorned with more than 300 inscriptions, most of them naming educational institutions. My former teacher of Latin authors, Latin composition, Latin paleography, and Medieval Latin, Professor Andries Welkenhuysen, produced an edition of them at the occasion of 575 years University of Louvain in 2000 (Welkenhuysen, 2005). The Catholic University of America is no. 180, one of 20 found in the so-called gallery. Among the others are UPenn (no. 162), Princeton (166), Yale (169), Harvard (170), Columbia (171), and Cornell (173).

The Library is an imposing building. I saw it voted one of the ten most impressive library buildings in the world somewhere on the Internet. Do pay it a visit and maybe look at some inscriptions. And the old town of Louvain east of Brussels is quite good-looking as well. The huge impressive open space in front of the library is now free of cars and traffic. And it is called the Ladeuze Place, as it was when I was a student in Louvain, after the Coptologist and rector or president of the university for more than 30 years and Hyvernat's personal acquaintance and correspondent. Ladeuze died in the night of 9 to 10 February 1940 and therefore was spared living through the Louvain Library fire of May, in which so many treasures were lost.

That completes my brief personal perspective on the life of Henri Hyvernat. Coptic Studies is a small world.

\section{Epilogue}

It seems proper to end this lecture by citing Daniel 12:3, which is the theme of the homily by Monsignor McCormick, then the Vice-Rector of this institution, read at Hyvernat's funeral mass. In Hebrew, the verse is as follows:

והמשכילים יזהירו כזוהר הרקיע ומצדיקי הרבים ככוכבים לעולם ועד

The translation of the Oxford New Revised Standard Version is as follows:

"Those who are wise shall shine like the brightness of the sky, and those who lead many to righteousness, like the stars forever and ever.”

I say Amen to that.

\section{Acknowledgements}

I am grateful to the editors of this journal for agreeing to retain the original styling of the text as a lecture rather than converting it into a typical journal article, a choice of style that duly honors the memory of Henri Hyvernat. I also thank my colleagues in the Department of Semitic and Egyptian Languages and Literatures of the Catholic University of America, Monica Blanchard, Aaron Butts, Edward Cooke, Sidney Griffith, Andrew Gross, Shawqy Talia, and Janet Timbie, as well as many graduate students, for the cordial reception and for the many stimulating conversations that took place over the course of my two-to-three-day stay on campus.

Dr. Blanchard, the Curator of the Institute for Christian Oriental Research founded by Hyvernat, has compiled a detailed biographical report (Blanchard, 2015). I was grateful to receive from her a copy of this valuable document. In fact, copies of this detailed 49-page study were distributed to all members of the audience on the occasion of the lecture. Dr. Blanchard also forwarded to me all kinds of materials pertaining to Hyvernat in the weeks leading up to the lecture and I perused them all diligently. Two recent biographical studies on Hyvernat are Calvet, 1998 and Griffith \& Blanchard, 1998.

Also, upon arrival in Washington, I was able to visit Hyvernat's tomb at Mount Olivet Cemetery, where the Catholic University of America holds a few plots, some distance away from the campus. The tomb was recently featured in The Catholic University of America Magazine (Gardner, 2013). I am grateful to two doctoral candi- 
dates of the Department of Semitic and Egyptian Languages and Literatures, Ms. Ryann Craig and Ms. Alison Tsukada, for showing me the way and accompanying me on this visit. Ms. Craig served as my main liaison in the course of the preparation for my visit and during it.

Last but not least, I thank the anonymous donor who makes the Hyvernat lectures possible. It is a most worthy cause indeed.

\section{References}

Blanchard, M. J. (2015). Henri Hyvernat (1858-1941): “The Grand Old Man of the University.” Private Publication. Copies May Be Available upon Request from the Institute for Christian Oriental Research and the Department of Semitic Languages and Literatures of the Catholic University of America.

Calvet, Y. (1998). Un orientaliste méconnu, l’Abbé Hyvernat. Bulletin de la Diana, 57, 3-28.

Depuydt, L. (2010). Coptic and Coptic Literature. In A. B. Lloyd (Ed.), A Companion to Ancient Egypt (pp. 732-754). Chichester: Wiley-Blackwell. http://dx.doi.org/10.1002/9781444320053.ch33

du Bourguet, P. (1991). Copt. In The Coptic Encyclopedia (pp. 599-601). New York: Macmillan.

Fricke, G. (1955). Friedrich Schiller: Briefe. Munich: Carl Hanser Verlag.

Gardner, J. (2013). In Their Shadows. The Catholic University of America Magazine, Summer 2013, 26-27.

Griffith, S., \& Blanchard M. (1998). Henri Hyvernat (1858-1941) and the Beginning of Syriac Studies at the Catholic University of America. Aram, 5, 181-196.

Kasser, R. (2006). Kat’aspe aspe. In L. Painchaud, \& P. H. Poirier (Eds.), Coptica—Gnostica—Manichaica: Mélanges offertes à Wolf-Peter Funk (pp. 389-492). Leuven: Peeters.

Müller, C. D. G. (1991). Benjamin I. In The Coptic Encyclopedia (pp. 375-377). New York: Macmillan.

Polotsky, H. J. (1971). Collected Papers. Jerusalem: The Magnes Press, The Hebrew University.

Welkenhuysen, A. (2005). Corpus Inscriptionum Bibliothecae Lovaniensis (CIBL). 356 Inscriptions at the Leuven University Library: Inventory, Publication, Annotations. In Chr. Coppens, M. Derez, \& J. Roegiers (Eds.), Leuven University Library. Leuven: Leuven University Press. 